University of Texas Rio Grande Valley

ScholarWorks @ UTRGV

$12-2012$

\title{
Explaining the Accounting Disclosure Index of Stock Exchanges by Foreign Exchange Market Activity
}

Aziz Bakay

Murad Moqbel

University of Texas Rio Grande Valley, murad.moqbel@utrgv.edu

Follow this and additional works at: https://scholarworks.utrgv.edu/is_fac

Part of the Business Commons

\section{Recommended Citation}

Bakay, A. and Moqbel, M. (2012) 'Explaining the accounting disclosure index of stock exchanges by foreign exchange market activity', Advances in Accounting, 28(2), pp. 293-297. doi: 10.1016/ j.adiac.2012.09.006.

This Article is brought to you for free and open access by the Robert C. Vackar College of Business \& Entrepreneurship at ScholarWorks @ UTRGV. It has been accepted for inclusion in Information Systems Faculty Publications and Presentations by an authorized administrator of ScholarWorks @ UTRGV. For more information, please contact justin.white@utrgv.edu,william.flores01@utrgv.edu. 


\title{
Explaining the Accounting Disclosure Index of Stock Exchanges by Foreign Exchange Market Activity *
}

\author{
Aziz BAKAY \\ Ph.D Student, Texas A\&M International University \\ 5201 University Boulevard, WHTC 211, Laredo, TX, 78041. \\ Office: (956) 326-2552 Email: azizbakay@dusty.tamiu.edu \\ Murad MOQBEL \\ Ph.D Student, Texas A\&M International University \\ 5201 University Boulevard, WHTC 211, Laredo, TX, 78041. \\ Office: (956) 326-2552 Email: muradmoqbel@dusty.tamiu.edu
}

\begin{abstract}
In this article, researcher-created accounting disclosure index of 23 stock exchanges for the year 1992 and its relationship with variables including foreign exchange turnover, economic and financial indicators are investigated. The accounting disclosure index of global stock exchanges crafted by Adhikari and Tondkar (1992) is regressed on foreign market turnover which is utilized as a proxy for foreign exchange market activity. The OLS results support that along with the activity of foreign exchange market; GNI per capita, market capitalization, energy and electric consumption, number of listed companies are significantly related with the accounting disclosure index. The foreign market turnover is found to be positively influencing the accounting disclosure index. The model explains the $73 \%$ of the variation in the index with an F-ratio of 26.56 indicating the overall significance of the model.
\end{abstract}

- We would like to thank Professor L. Murphy Smith for his comments. 


\section{INTRODUCTION}

Different social, political, regulatory environments create different accounting disclosure requirements for firms across the countries. It is clear to expect variation in the requirements of information disclosure of public firms traded in a stock exchange in Switzerland (SIX Swiss Exchange) compared to a firms traded in stock exchange of Turkey (Istanbul Stock Exchange). Requirements for information disclosure in part reflect the transparency and accountability of the public firms.

Accounting standard setters are continuously maintaining the accuracy and transparency of the disclosures by monitoring and providing additional guidelines and issuance of new requirements. FASB has issued recently new disclosure requirements pertaining to application of fair value measurement provisions of US GAAP (Pounder, 2010). Therefore the decision making mechanism might be twisted accordingly to new disclosure requirements. An earlier study found that by surveying the institutional investors, corporate issuers and market regulators, capital market decisions are affected by such diversity in the international markets (Choi \& Levich, 1991).

Ahmed and Courtis (1999) investigated the literature on the association between the accounting

disclosure levels and corporate characteristics. Among various factors, their meta-analysis results support that the corporate size, listing status and leverage are positively and significantly influencing the disclosure levels. The correlation coefficients of these variables with the disclosure level are $0.3,0.3$ and 0.2 respectively. On the other hand, the accounting disclosure levels -higher or lower- are determined regardless of the profitability of the corporation, and the 
size of the audit firm. Earlier studies examined the accounting disclosure comprehensiveness and levels along with the corporate characteristics in different countries including Hong Kong (Wallace \& Naser, 1995), United Kingdom (Wallace, Choudhury \& Adhikari, 1999). The former study suggests that there is relationship between the mandatory information enclosed in the annual reports of corporations with the researcher-created indices of the comprehensiveness of accounting disclosure. Significant covariations with several indicators of firm, i.e. scope of the business and asset size are found. These variables are evidenced to be positively associated with the comprehensiveness index. Similarly, the latter study empirically proves that firm size is positively, return on sales is negatively related with the comprehensiveness of cash flow reporting.

Accounting disclosure index for the year 1992 was created by Adhikari and Tondkar (1992) who focused on its relationship with environmental factors. These factors include degree of economic development, type of economy, size of the equity market (market capitalization), activity on the equity market (market turnover), and dispersion of stock ownership in the equity market. Findings suggest that among these factors, only market capitalization is significantly explaining the index. This index has a score for 35 exchange markets (Stock exchange -SE) all over the world including Austria (Vienna SE), Finland (Helsinki SE), Korea (Seoul SE), Portugal (Lisbon SE), Turkey (Istanbul SE) along others (Exhibit 1). Authors have picked only one stock exchange from each country. The index is crafted by the authors as the following: A survey that included 44 items asking about listing and filing information requirements of stock exchanges was designed. The design is completed after a thorough review of the literature on information disclosure requirements and review of the listing and filing requirements of the NYSE, London 
SE, Tokyo SE that are considered to be the most precise accounting disclosure and reporting practices. Survey was sent to 287 experts in international equity market in 41 countries ( 7 experts in each country). $52 \%$ response rate was recorded. By giving weight to some information items more importance relative to the literature, they ended up having both weighted and unweighted indices.

The accounting disclosure has been examined in many ways in earlier studies; however, the niche point that we are analyzing in this particular study is that the association between, if any, accounting disclosure index of selected 23 global stock exchanges and foreign exchange market activities in these countries. Thus, we utilize aforementioned researcher-created index as our dependent variable. The rationale behind including the foreign exchange market turnover as a variable in our analysis is the following: Stock exchanges include firms operating in international environment in which exchange risk is of high importance. If a stock market is exposed to international exchange risk, then stock exchange receives more pressure to disclose information in detail and in more transparency. Hence, as the internationalization of a stock exchange builds up, the more qualified accounting disclosure requirements of stock exchanges are observed leading to better accounting disclosure scores.

\section{METHODOLOGY}

\section{Variables}

The accounting disclosure index is obtained from earlier study by Adhikari and Tondkar (1992). In their study, scores are calculated for 35 stock exchanges and we could incorporate only 23 of those due to data limitation. Unweighted index provided better results for this particular study 
and we will disclose the results of both. Since the mentioned study was published in 1992, the index is assumed to be valid for the year 1992 and observations of other variables for the year 1992 were obtained. Having only observations for the year 1992, might arise analytic problems as conducting regression with very limited number of observations ( 23 observations). Therefore, for the second stage of our data collection, we would assume that accounting disclosure index is valid for the years 1989 and 1995 as well as 1992, for which we were able to pull the foreign exchange market turnover data. This would allow us to enlarge our data set to 64 observations.

As the focal relationship in the model, we utilize the foreign exchange turnover as a measure the activity of the exchange market (Bank for International Settlements, 1996). The contracts are segmented into three categories of spot, forward and swaps. In the year 1992, almost half of the contracts are spot and the remaining is shared by forwards and swaps (Exhibit-2). In 1992, foreign exchange turnover reached $\$ 800$ billion and in 1995 it reached just below of $\$ 1.2$ trillion. $82 \%$ of all of these foreign exchange contracts have dollar as currency on side of the contract, followed by Deutsche Mark (40\%) and Japanese Yen (27\%) (BIS, 1996). Great Britain as the financial center of the World ranks the highest in terms of the foreign exchange market turnover and it takes up to $30 \%$ of the foreign exchange turnover globally. It is followed by US and Japan (Exhibit-3). The data is available every three years due to the fact that the central bank survey conducted globally by Bank for International Settlements in every three years.

As a standard measurement of the economic development of the country, GNI per capita is included in the model. It is rather GNI per capita than GDP due to the fact that the income generated by businesses abroad by nationals could be incorporated and their influence could be 
ruled out. We have operationalized Market capitalization of listed companies as a percentage ratio of GDP in the model. This variable is a measure to capture the development level of the stock exchange in terms of the sizes of the listed companies. We included two variables to measure the transportation and technological advancement in the country: energy consumption in $\mathrm{kg}$ of oil equivalent per capita and electric consumption. These are proxies for identifying the stage of the economy in the sense of industrialization as well as these are indicators of the level of economic development in countries. Similarly for the same purpose, Adhikari and Tondkar (1992) included type of economy measured as agricultural output divided by GDP. Lastly, the number of domestic listed companies in the stock exchange divided by the population is included in the model. Therefore, the extent of which the stock market involves domestic firms as opposed to MNEs listed in the stock exchange could be captured.

\section{Estimation Method}

We will utilize the following OLS regression analysis:

$$
\begin{aligned}
\text { DSCLSR }_{\mathrm{i}}= & \alpha+\beta_{1}\left(\text { TURNOVER }_{\mathrm{i}}\right)+\beta_{2}\left(\text { MRKTCAP }_{\mathrm{i}}\right)+\beta_{3}\left(\text { GNIPERCAP }_{\mathrm{i}}\right)+ \\
& \beta_{4}\left(\text { ENGRYU }_{\mathrm{i}}\right)+\beta_{5}\left(\text { ELCTRC }_{\mathrm{i}}\right)+\beta_{6}\left(\text { LISTEDC }_{\mathrm{i}}\right)+\epsilon_{\mathrm{t}}
\end{aligned}
$$

Where;

DSCLSR $_{\mathrm{i}}$ : A composite accounting disclosure index of stock exchange $i$.

MRKCAP $P_{\mathrm{i}}$ : Market capitalization of listed companies as $\%$ of GDP of country $i$.

GNIPERCAP $_{\mathrm{i}}$ : Gross National Income of country $i$ in current international dollars (Purchasing Power Parity)

ENGRYU $_{\mathrm{i}}$ : Energy use in kg of oil equivalent per capita in country $i$.

ELCTRC $_{\mathrm{i}}$ : Electric power consumption in kWh per capita in country $i$. 
LISTEDC $_{\mathrm{i}}$ : Number of domestic listed companies in the stock exchange divided by the population of the country $i$.

TURNOVER : Foreign Exchange Market turnover in billions of US dollars for the country $i$.

Foreign exchange turnover in 1989, 1992 and 1995 in the countries selected is derived from the foreign exchange market statistics of Bank of International Settlement (1996). Turnover includes three types of contracts: spot, forward and swap. The rationale behind is that developed stock markets have higher accounting disclosure requirement scores. In addition, developed stock markets include higher number of MNEs' stocks. These MNEs operate in an international business environment in which firms are exposed to exchange rate risk. More spot contracts are expected for their everyday business transactions. Moreover, for the purposes of risk management, forward and swap contracts become crucial. Therefore foreign exchange turnover is employed as a proxy to measure the activity in foreign exchange market and it is used as an explanatory variable so that we could observe its role in the accounting disclosure index. We hypothesize that the higher activity in the foreign exchange market contributes to the accounting disclosure requirement score of the stock exchange. Hence, the expected coefficient of foreign exchange turnover is positive.

\section{Data}

The sample consists of 64 observations. The index is gathered from Adhikari and Tondkar (1992). Market capitalization of listed companies in stock exchanges, GNI per capita, energy 
use, electric consumption, number of domestic listed companies, population are obtained from World Economic Indicators database. The summary statistics are presented in Exhibit 4.

\section{Cross-correlations of Variables}

As it is presented in Exhibit 5, the weighted and unweighted accounting disclosure indices are highly correlated (0.9984). In our analysis, we used both variables in order to check the robustness of the model resulting in slightly better results with weighted index. Secondly, the correlations between indices and turnover are also substantial $(0.66,0.65)$. Only 5 out of 22 cross-correlations are higher than 0.5 (excluding correlations of variables with unweighted DSCLRS). In order to check for multicollinearity, we have utilized variance inflation factor (VIF) in STATA (Exhibit 6). VIFs for variables are not exceeding 4 which are at acceptable levels. A VIF value that is higher than 10 would be considered as problematic. Hence, we conclude that there is no collinearity problem.

\section{Regression Results}

We find significant results for all the variables in the first three models (Exhibit 7) except for LISTEDC in the fourth model. All the TURNOVER coefficients are significant under $1 \%$. In the first three models all variables except LISTEDC are significant at 1\% level. MARKCAP coefficients are significant and positive. In overall, models are significant considering the Rsquared values of $73 \%$ and $72 \%$ for unweighted and weighted models respectively. However, the R-squared of the model without the electricity power consumption and energy use drops to $49 \%$. For all the models, F statistics are significant under 1\% level. 
These significant results could be due to the small sample size and the violation of normality for the dependent variable. Dependent variable's kurtosis value is 2.84 (Exhibit 8) that is more than twice of the standard error of kurtosis $\left(. \operatorname{sek}=\sqrt{\frac{24}{N}}, \mathrm{~N}=69\right)$ resulting in tall distribution (Brown, 1997).

Turnover has the positive coefficients in all the models. Coefficients are 0.0484 and 0.0471 for weighted and unweighted models respectively. Interpretation of this coefficient is that approximately $\$ 20$ billion increase in the foreign exchange turnover, the accounting disclosure score of the exchange increases 1 point. Surprisingly, GNI per capita has a negative coefficient in all the models as well as electric power consumption. However these two variables do not have substantially large coefficients meaning changes in these variables would impact the accounting disclosure index very little compared to other variables in the model. Energy usage influences the index positively. In addition, market capitalization of listed firms in the stock exchange has a positive impact on the index. Listed domestic companies (scaled by the population) has a similar magnitude with market capitalization however a negative impact.

In the third column of exhibit 7, we presented the standardized coefficients. By definition, one standard deviation change in independent variables might be compared by looking into standardized coefficients of predictors. Interpretation of the standardized regression coefficients could be illusionary. Therefore, relative importance of the variable could be inferred from the simple comparison. Admitting these facts, in our table the standardized coefficient of the TURNOVER is the smallest, indicating the fact that it might have the lowest relative importance among the other variables in explaining the index. Therefore, one standard deviation (SD) 
change in TURNOVER corresponds to $\$ 78$ billion ( $\mu=\$ 51.27$ ) change would lead to 0.0484 SD change in the index. On the other hand, one SD change in TURNOVER may not be as easy as one SD change in the ENGRYU which corresponds to approximately $1882 \mathrm{~kg}$ of oil equivalent ( $\mu=4352)$. However, one SD change in ENGRYU will lead to a 0.0036 SD change in the index.

\section{DISCUSSION AND CONCLUSION}

In this study, our primary goal was to explore the association between the foreign exchange market activity and the accounting disclosure requirement scores of stock exchanges. The accounting disclosure scores that were constructed by an earlier study are utilized as the disclosure index. It included 35 stock exchanges across the world however the availability of data of the foreign exchange turnover reduced it to 23 stock exchanges. Several explanatory variables from the World Development Indicators are operationalized to control for the development of the stock market including the extent of MNEs involvement and economic development level of the country. Statistical results support our hypothesis that higher foreign exchange market activity which is proxied by foreign exchange turnover, improve the disclosure index. Therefore, better accounting practices and oversight are associated with higher activity in the foreign exchange market. On the other hand, the number of listed domestic companies scaled by the population has unsurprisingly a negative relationship with the disclosure index. In our opinion, this may be due to the fact that lower number of domestic listed companies indicates higher number of listed MNEs in the stock exchange. MNEs increase the exposure of the stock exchange to international operations therefore, for the sake of obtaining more transparent information; disclosure requirements are adjusted and/or improved. Therefore, the MNEs capital 
requirements are financed through international investors and creditors that are looking for more detailed and improved accounting information disclosure.

Future studies can extend the data set and further the findings as well as including various environmental factors to explore their association with the accounting disclosure scores. Besides, broadening the angles looking into foreign exchange market activity might be furthered by considering the futures market and taking security market activities into account so that the accounting disclosure ratings of stock exchanges could be investigated in a different way. 


\section{REFERENCES}

Adhikari, A. \& Tondkar, R., H. (1992). Environmental Factors Influencing Accounting Disclosure Requirements of Global Stock Exchanges. Journal of International Financial Management \& Accounting, 4(2), 75.

Ahmed, K. \& Courtis, J., K. (1999). Associations between Corporate Characteristics and Disclosure Levels in Annual Reports: A Meta-Analysis. The British Accounting Review, 31(1), 35-61.

Bank for International Settlements (1996). Central Bank Survey of Foreign Exchange and Derivatives Market Activity, 1995. Basle, Switzerland: BIS.

Brown, J. D. (1997, April). Skewness and Kurtosis. Shiken: JALT Testing \& Evaluation SIG Newsletter, 1 (1), 20-23. Retrieved on April 20, 2010 from http://jalt.org/test/PDF/Brown1.pdf

Choi, F., D., S. \& Levich, R., M. (1991). International Accounting Diversity: Does It Affect Market Participants? Financial Analysts Journal, 47(4), 73.

Pounder, B. (2010). Another Step along the Path to Transparency. Strategic Finance, 91(9), 1516,61 . 
Wallace, R., S., O. \& Naser, K. (1995). Firm-Specific Determinants of the Comprehensiveness of Mandatory Disclosure in the Corporate Annual Reports of Firms Listed on the Stock Exchange of Hong Kong. Journal of Accounting and Public Policy, 14(4), 311.

Wallace, R., S., O., Choudhury, S., I., M. \& Adhikari. A. (1999). The comprehensiveness of cash flow reporting in the United Kingdom: Some characteristics and firm-specific determinants. The International Journal of Accounting, 34(3), 311-347. 


\section{EXHIBIT 1}

\section{Accounting Disclosure Index}

$\begin{array}{llcc}\text { Country } & \text { City of Stock Exchange } & \text { Weighted } & \text { Unweighted } \\ \text { 1Australia } & \text { Sydney } & 74.6 & 74.64 \\ \text { 2Austria } & \text { Vienna } & 54.17 & 53.52 \\ \text { 3Canada } & \text { Toronto } & 79 & 78.64 \\ \text { 4Denmark } & \text { Copenhagen } & 67.2 & 66.86 \\ \text { 5Finland } & \text { Helsinki } & 70.54 & 71.05 \\ \text { 6France } & \text { Paris } & 76.2 & 76.16 \\ \text { 7Germany } & \text { Frankfurt } & 67.2 & 66.86 \\ \text { 8Greece } & \text { Athens } & 60 & 59.41 \\ \text { 9Hong Kong } & \text { Hong Kong } & 77.04 & 75.77 \\ \text { 10Italy } & \text { Milan } & 68.46 & 68.39 \\ \text { 11 Japan } & \text { Tokyo } & 77.68 & 77.68 \\ \text { 12 Luxembourg } & \text { Luxembourg } & 66.62 & 66.64 \\ \text { 13Netherlands } & \text { Amsterdam } & 73.19 & 72.84 \\ \text { 14New Zealand } & \text { Wellington } & 67.13 & 65.91 \\ \text { 15Norway } & \text { Oslo } & 60.63 & 60.59 \\ \text { 16 Portugal } & \text { Lisbon } & 65.68 & 65.5 \\ \text { 17Singapore } & \text { Singapore } & 80.89 & 80.32 \\ \text { 18South Africa } & \text { Johannesburg } & 74.5 & 73.48 \\ \text { 19Spain } & \text { Madrid } & 68.84 & 68.36 \\ \text { 20Sweden } & \text { Stockholm } & 60.54 & 60.05 \\ \text { 21Switzerland } & \text { Zurich } & 72.19 & 71.7 \\ \text { 22UK } & \text { London } & 86.21 & 84.86 \\ \text { 23US } & \text { New York } & 90.31 & 90.75\end{array}$

Source: Adhikari \& Tondkar (1992). 


\section{EXHIBIT 2}

Estimated Global Foreign Exchange Market Turnover by Market Segment in April 1989, April 1992, April 1995.



- Average daily turnover, in billions of US dollars.

Source: Bank for International Settlements, 1996 


\section{EXHIBIT 3}

\section{Reported Foreign Exchange Market Turnover in Major Centres}

in April 1989, April 1992, April 1995.

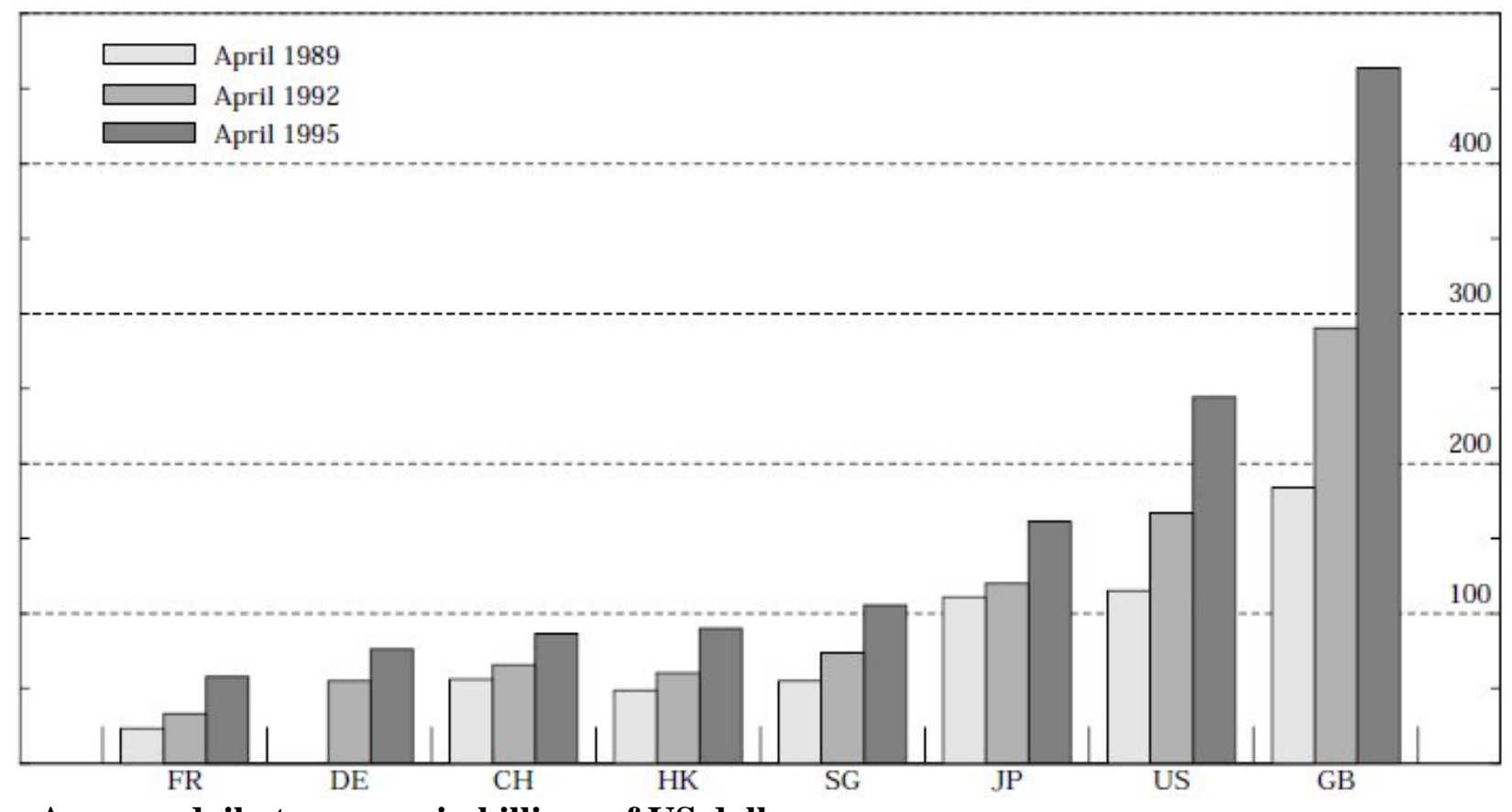

- Average daily turnover, in billions of US dollars

Source: Bank for International Settlements, 1996 


\section{EXHIBIT 4}

\section{Summary Statistics}

\begin{tabular}{r|c|c|c|c}
\multicolumn{1}{c|}{ Variables } & Mean & Std. Dev. & Min & Max \\
\hline Weighted DSCLSR & 71.25 & 8.60 & 54.17 & 90.31 \\
\hline Unweighted DSCLSR & 70.86 & 8.62 & 53.52 & 90.75 \\
\hline TURNOVER & 51.27 & 78.89 & 0.4 & 463.8 \\
\hline GNIPERCAP & 18728.55 & 5459.67 & 5420 & 36140 \\
\hline MRKCAP & 59.80 & 48.14 & 8.37 & 210.57 \\
\hline ELCTRC & 8249.25 & 5094.03 & 2415.71 & 24523.85 \\
\hline ENGRYU & 4352.67 & 1882.86 & 1635.80 & 9687.00 \\
\hline LISTEDC & 3.28 & 3.08 & 0.38 & 15.04
\end{tabular}

\section{EXHIBIT 5}

\section{Correlation Matrix}

\begin{tabular}{r|c|c|c|c|c|c|c|c} 
& $\begin{array}{c}\text { Weighted } \\
\text { DSCLSR }\end{array}$ & $\begin{array}{c}\text { Unweighted } \\
\text { DSCLSR }\end{array}$ & TURNOVER & GNIPERCAP & MRKCAP & ELCTRC & ENGRYU & LISTEDC \\
\hline $\begin{array}{r}\text { Weighted } \\
\text { DSCLSR }\end{array}$ & 1 & & & & & & & \\
\hline $\begin{array}{r}\text { Unweighted } \\
\text { DSCLSR }\end{array}$ & 0.9984 & 1 & & & & & & \\
\hline TURNOVER & 0.6647 & 0.6515 & 1 & & & & & \\
\hline GNIPERCAP & 0.1009 & 0.1163 & 0.2324 & 1 & & & & \\
\hline MRKCAP & 0.5305 & 0.5077 & 0.4186 & 0.2600 & 1 & & & \\
\hline ELCTRC & -0.1199 & -0.0984 & -0.0945 & 0.3667 & -0.0946 & 1 & & \\
\hline ENGRYU & 0.2840 & 0.3098 & 0.1089 & 0.5922 & 0.0889 & 0.7170 & 1 & \\
\hline LISTEDC & 0.1303 & 0.1258 & 0.0496 & 0.5132 & 0.4804 & 0.2159 & 0.4534 & 1
\end{tabular}

\section{EXHIBIT 6}

\section{Variance Inflation Factors}

\begin{tabular}{r|r|r}
\multicolumn{1}{c|}{ Variable } & \multicolumn{1}{|c|}{ VIF } & \multicolumn{1}{|c}{ /VIF } \\
\hline ENGRYU & 3.09 & 0.32 \\
\hline ELCTRC & 2.28 & 0.43 \\
\hline LISTEDC & 1.99 & 0.50 \\
\hline GNIPERCAP & 1.83 & 0.54 \\
\hline M RKCAP & 1.73 & 0.57 \\
\hline TURNOVER & 1.42 & 0.70 \\
\hline & & \\
\hline M ean VIF & 2.06 &
\end{tabular}




\section{EXHIBIT 7}

\section{Regression Results}

Dependent variable: Accounting Disclosure index

\begin{tabular}{|c|c|c|c|c|}
\hline $\begin{array}{l}\text { Type of dependent } \\
\text { variable }\end{array}$ & Weighted & Unweighted & $\begin{array}{c}\text { (Robust std errors) } \\
\text { Weighted }\end{array}$ & Unweighted \\
\hline & Coefficient & Coefficient & $\begin{array}{l}\text { Standardized } \\
\text { Coefficient }\end{array}$ & $\begin{array}{l}\text { Without energy and } \\
\text { electric consumption }\end{array}$ \\
\hline \multirow[t]{2}{*}{ TURNOVER } & $0.0484 * * *$ & $0.04712 * * *$ & $0.0484 * * *$ & $.0585 * * *$ \\
\hline & $(0.0086)$ & $(0.0089)$ & & $(.0115)$ \\
\hline \multirow[t]{2}{*}{ GNIPERCAP } & $-0.0005 * * *$ & $-0.0004 * * *$ & $-0.0005^{* * *}$ & $-.0001 *$ \\
\hline & $(0.0001)$ & $(0.0001)$ & & $(.0001)$ \\
\hline \multirow[t]{2}{*}{ M RKCAP } & $0.0691 * * *$ & $0.0663 * * *$ & $0.0691 * * *$ & $.0526 * *$ \\
\hline & $(0.0155)$ & $(0.0159)$ & & $(.0205)$ \\
\hline \multirow[t]{2}{*}{ ELCTRC } & $-0.0007 * * *$ & $-0.0007 * * *$ & $-0.0007 * * *$ & \\
\hline & $(0.0001)$ & $(0.0001)$ & & \\
\hline \multirow[t]{2}{*}{ ENGRYU } & $0.0036 * * *$ & $0.0038 * * *$ & $0.0036 * * *$ & \\
\hline & $(0.0005)$ & $(0.0005)$ & & \\
\hline \multirow[t]{2}{*}{ LISTEDC } & $-0.5517^{*}$ & $-0.6017^{* *}$ & $-0.5517 *$ & -0.0044 \\
\hline & $(0.2887)$ & $(0.2974)$ & & $(.3725)$ \\
\hline Constant & 66.7605 & 65.7980 & 66.7605 & \\
\hline R-squared & 0.7365 & 0.7212 & 0.7365 & 0.4986 \\
\hline Adj R-squared & 0.7088 & 0.6918 & & 0.4646 \\
\hline$F(6,57)$ & 26.56 & 24.57 & 25.03 & 14.67 \\
\hline Prob $>F$ & 0.0000 & 0.0000 & 0.0000 & 0.0000 \\
\hline
\end{tabular}

$* * *$ for $1 \%, * *$ for $5 \%, *$ for $10 \%$ significance. 


\section{EXHIBIT 8}

Detailed Summary Statistics of Weighted Disclosure Scores for Stock Exchanges

\begin{tabular}{r|ll|r|l} 
& Percentiles & \multicolumn{2}{l|}{ Smallest } & \\
\hline $\mathbf{1 \%}$ & 54.17 & 54.17 & & \\
\hline $\mathbf{5 \%}$ & 60 & 54.17 & & \\
\hline $\mathbf{1 0 \%}$ & 60.54 & 54.17 & Observation & 69 \\
\hline $\mathbf{2 5 \%}$ & 66.62 & 60 & Sum of Wgt. & 69 \\
\hline $\mathbf{5 0 \%}$ & 70.54 & & Mean & 71.2530 \\
\hline & & Largest & Std. Dev. & 8.4748 \\
\hline $\mathbf{7 5 \%}$ & 77.04 & 86.21 & Variance & 71.8233 \\
\hline $\mathbf{9 0 \%}$ & 80.89 & 90.31 & Skewness & .2143 \\
\hline $\mathbf{9 5 \%}$ & 86.21 & 90.31 & Kurtosis & 2.8403 \\
\hline $\mathbf{9 9 \%}$ & 90.31 & 90.31 & &
\end{tabular}

